\title{
ESP Needs of Midwifery Students of Sari Mulia University on Preparing Credit Transfer Program to Overseas
}

\author{
Maulida Rahmah \\ \{maulidarahmah@unism.ac.id\} \\ Sari Mulia University, J1. Scout 2, PemurusAffairs. District. East Banjarmasin, Banjarmasin, \\ South Kalimantan, 70 238, Indonesia
}

\begin{abstract}
Need analysis on English Specific Purposes (ESP) is needed to identify the teaching material on the process of selecting, adapting and evaluating based on students' necessity. The research aimed to investigate the needs midwifery students on learning English through interview based on a needs analysis. It focused on the material that was balanced between "General English" and "Specific English" in the term of syllabus and the classroom activities. The research applied descriptive qualitative method and involved 28 midwifery students at $6^{\text {th }}$ semester. The result revealed that "General English" is crucial as it enables midwifery students for communicating with patients and escalates them as individually. It was also found that the classroom activities should be supported by speaking and listening course. Furthermore, the "Specific English" should be provided gradually and consisted of vocabulary, content and function used by midwifery working in medical profession.
\end{abstract}

Keywords: needs analysis, midwifery students, ESP

\section{Introduction}

English is widely used in academic world. The high demand of professional and qualified worker in the workplace, both inside and outside of Indonesia, encourages the school to improve the quality of the education by including English, an international language of communication, as one of the subjects which is compulsory to attend by the students. At the University levels, English also receives a growing concern. It is not only taught for students of English department but also students across disciplines. This happens at Sari Mulia University. All Departments provide English as one of the subject that the students should get. One of department which has transfer credit program doing practicum at one of universities in overseas is Midwifery Department namely Diploma III Midwifery. On the sixth semester, the students will get the program and should pass it. The most important thing step to prepare the students is to learn English language as an International Language which will help them to communicate during their 
program by giving English subject which is English for Specific Purposes (ESP) and General English.

According to Hutchinson and Waters, " ESP is an approach to language teaching in which all decisions as to content and method are based on the learner's reason for learning." Following on this concept, it is required to gain understanding of the needs of our learners if we are to support EFL teachers in deciding what to teach and how to implement the most suitable method to help learners achieving fulfilling learning experience.

Celce-Murcia (2001) stated that ESP is a movement based on the proposition that all language teachings should be tailored to the specific learning and language use needs for identified group of learners and also sensitive to the social-cultural context in which these learners will use English. ESP is generally known as a learner-centered approach, since it meets the needs of (mostly) adult learners who need to learn a foreign language use in their specific fields, such as nursing, science, technology, hospitality, academic learning, etc.

One of the driving factors behind the development is the necessity to address the needs of learners. According to Dudley-Evans and St. John, addressing the language required and learning context of learners is a cornerstone of ESP : "Need is defined by the reasons for which the students is learning English, which will vary from study purposes such as following a postgraduate course in an English speaking country to work purposes such as participating in business meetings or taking hotel bookings."

Basturkmen (2006) stated that the most prominent feature in ESP course design is that the syllabus based on analysis of the students' need, because in ESP language is learnt to equip the learners to entry a more specific linguistic environment.

Need analysis is generally considered the cornerstone of ESP course design (Dudley-Evans \& St John, 1998). It is the basis of language learning programs which leads to focused language learning course and aid the development and improvement on the programs. Robinson States that a need analysis aims to specify as closely as possible what exactly it is that students have to do through the medium of English.

Dudley-Evan defines a need analysis as establishing process how and what for a subject. Regarding to need analysis in ESP covered:

a. TSA (Target Situational Analysis) and objective needs are to get information about the students, the assignment and the students activity.

b. Wants, means, subjective needs are the figure out the information about the students, some factors that influence their learning style, such as their past experience in studying, their culture information, some reasons for coming to the course and their expectation on it.

c. PSA (Present Situational Analysis) is the analysis technic to find out about the information of language of the students, such as what the current skill that they have.

d. Lack is the need analysis about the gap between (c) and (a).

e. Learning needs is the need analysis about the information of the students in terms of the appropriate ways in learning skills and language in (d).

f. Linguistic analysis, discourse analysis, and genre analysis are the need analysis to get the information about (a) the language and skills are used in target situation.

g. Means analysis is to get information about the surrounding where the course will be carried out. 
The aims of this paper to investigate the needs midwifery students on learning English through interview based on a needs analysis, applying the expressed ideas above as a guide, and to discuss the implication for English as a Foreign Language teachers in designing classroom activities. In this investigation, the researcher applied the terms "General English" and Specific English" in interviews. General English is the wide range of language items and functions likely to be used in interaction and communication with speakers of the English Language. Meanwhile, specific English is the English content and functions likely to be encountered by midwife working in the medical profession.

\section{Research Methodology}

This research applied a descriptive qualitative design. The subjects of this research were 28 midwifery students at $6^{\text {th }}$ semester. The researcher used observation and interview as the instrument. In this research, the researcher used semi-structured questions for the interview. That was because the researcher wanted to get specific data.

\section{Findings And Discussion}

\subsection{Findings}

In this section, the data collected from the interview are analyzed and discussed. Twenty eight students were interviewed for nine questions. These questions were expected that more detailed information was gained from the students.

Analysis of Data from the interview

a. How important do you think English is to your current medical studies?

In response of answering the question, all students perceived English as very important to learn for their current medical studies, one of the reason was some of the literature review of article or journal that they had to learn used English Language. Besides, they had a greet program which was practicum, transfer credit program, where the students had to master English to prepare themselves doing practicum in that program on one of universities in overseas where English served as the medium of communication.

b. How important do you think English is to your future careers?

Similar to the first question, all students answered that English was very important for their future. One of the requirements of applying for job is English skill. Moreover, it became the crucial point should have. Some students also mentioned that they wanted to work abroad as midwife. To achieve the dream, they had to learn and master English so that they would not have any problem in terms of communication.

c. How important do you think the purpose of using English is to succeed in academic studies?

Mostly students replied that the purpose of using English is to succeed in academic studies was important. Students thought that learning English could help to be successful in academic studies, because many things such as information and knowledge could be 
obtained from various sources in articles or journals that could add insight and knowledge in addition to explanations from their lecturers in class.

e. How important do you think the purpose of using English is to foster discussion skill in class or at medical meetings?

All students replied that it was important that the purpose of using English to foster discussion skill in class or at medical meetings, because they should use English for fostering discussion when they were doing practicum on transfer credit program.

f. What are the Learners wants and needs terms of activities ?

From all answers given by students, it could be summarize what learners wants and needs as follow:

1) Writing answer to examinations, assignments, summaries, and reports in English

2) Discussing with teachers or classmates, ask questions in English

3) Reading books, internet sources and short notes

4) Delivering presentation in English

5) Listening to lectures, discussions, presentations, recorded, etc.

6) Speaking about medical related topics in English.

7) Writing and reading about medical related topics in English.

8) Understanding medical related instructions, giving information, instructions, asking for cooperation, checking readiness, explaining medical information that is easy to understand, explaining procedures, asking permission

It could be seen that the learners need to learn language skills, general English and specific English as well. Regarding the learning of English skill, the students reported that speaking and listening are the most important skill for study. They used it for understanding daily conversation, discussion, presentation, and understanding the lectures. Meanwhile, understanding all the journal and article they need to master reading skill to get much information and knowledge regarding to the material. In addition, writing skill would support the ability to write research report, summaries, write for practical purposes, etc. Another valuable material was medical topic which was in English. All of about vocabularies related to medical topics. All these four skills and specific English were needed by the students to perform optimally in their study.

g. How important is learning General English? Why?

Most students perceived learning General English as very important for both study and practicum program. For them, general English is crucial to be mastered. By mastering general English, it would make them ease to understand about specific English. The students had different English proficiency, that was why the students needed to get general English to be an early stage in learning English.

h. How important is learning specific English? why?

All respondents perceived learning specific English especially English for midwifery in medical profession as very important for study. It would support them in understanding all the materials that they had to know around the workplace, such as vocabulary, the English content and functions likely to be encountered by midwife working in the medical profession.

i. How many hours a week do you study English?

On the Intensive English program the students got 3 hours a week to learn English, but mostly the material was about general English. 
j. What do you feel would be the best ratio of technical to general English to specific English? In response, all students replied that the best ratio was 50\% for general English and 50\% for specific English.

\section{Discussion}

This study describes a need analysis conducted to investigate the needs midwifery students on learning English through interview based on a needs analysis, applying the expressed ideas above as a guide, and to discuss the implication for English as a Foreign Language teachers in designing classroom activities. Result of interviews indicated that English was considered very important for midwifery students. Since using English, students could do and access many things more easily such as reading books, browsing internets to learn midwifery topics and materials where English is utilized. In this study, the students argued that speaking is needed since in their study and career, midwifery students had to communicate a lot with the patients in performing their duty in the delivery of midwifery care. The duty required the students to have excellent communication skills, and speaking plays a vital role in this context such as giving information, instructions, asking for cooperation, checking readiness, explaining medical information that is easy to understand, explaining procedures, asking permission, etc.

Regarding to the English skill( listening, speaking, reading and writing) within the course, it was indicated that the students reported the need of all four language skills to be concluded in the language program for a number reasons. The students learned and improved listening skill to understand daily conversation and lectures. They also learned reading to comprehend journals and read textbook to support speaking skill in carrying out daily conversation and present report on presentation. Furthermore, they needed to learn writing to write correct sentences, write various text, research reports and write for practical purposes. In other words, all of those skills were needed to learn to support the learning activities such as presentation, discussion, lectures, practicum, etc.

In addition, most students believed that the material they learned in English course should be relevant to their study. It was expected that by learning materials which were relevant to the discipline, students was able to relate what they had got in English course. As a result, the learning can be more meaningful since students learn what they have been exposed to. So, the combination of general English and specific English is necessary giving to the students balanced which had ratio 50\% each of them. It will support each other to help students achieve more success in their study. Specific English differs from general English since it broadens someone's knowledge about specific subject matter by offering intensively specialized vocabulary that in turn prepares learners to use the language in their future professions. The learners in an English for Specific Purposes course will frequently know more about the technical aspects of the subjects. On the other hand, general English prepares students for the kind of English they will need in everyday situations. It emphasizes the development of communication skills in listening, speaking, reading and writing skills. Vocabulary, grammar, and pronunciation are also taken into account. It can be said that "General English" is crucial as it enables midwifery students for communicating with patients and escalates them as individually. Then, the classroom activities should be supported by speaking and 
listening course. Furthermore, the " Specific English" should be provided gradually and consisted

of vocabulary, content and function used by midwifery working in medical profession.

\section{Conclusion}

Overall, this study showed an evidence that English is highly important for midwifery students for their current study especially for the preparation joining transfer credit program and for future careers. The students needed English for a number of purposes such us understanding lectures, understanding journals, presenting reports, carrying out daily conversations, discussion, and so on. They also wanted to get balanced of general English course and specific English course in their study.

\section{References}

[1] Ary Donald. Introduction to Research in Education (Six Edition). USA: Wadsworth Group a Division of Thomson Learning Inc. (2002).

[2] Basturkmen, H. Ideas and options in English for Specific Purposes. New Jersey: Lawrence Erlbaum Associates Publisher. (2006).

[3] Basturkmen, H. Developing Courses in English for Specific Purposes. New York : Palgrave Macmillan. (2010).

[4] Brown, H.D. Teaching by Principles: An Interactive Approach to Language Pedagogy(2 ${ }^{\text {nd }}$ Ed). New York: Addison Wesley Longman. (2001).

[5] Bogdan C.Robert, Biklen Knopp. Qualitative Research for Education: An Introduction to Theory and Methods. Bosten: Allyn and Bacon. Inc. (1993).

[6] Celce-Murcia, M. Language Teaching Approaches: An Overview. In Celce-Murcia. M. (Ed.). Teaching English as a second or foreign language

[7] Chia, H., Johnson, R., Chia, H. L., Olive, F. English for College Students in Taiwan: A study of perception of english needs in a medical context. English for specific purposes. Vol 18(2). 107-119. (1999).

[8] Dudley-Evans T. \& St John, M. J. Developments in English for Specific Purposes: A Multidiscilinary Approach. Cambridge UP. (1998).

[9] Harding, K. English for Specific Purposes. Oxford: Oxford University Press. (2007).

[10] Hutchinson, T. \& Waters. A. English for Specific purposes: A learning-centered approach. Cambridege: Cambridge University Press. (1987).

[11] Miyake, M., \& Tremarco, J. Needs analysis for Nursing Students Utilizing Questionnaires and Interviews. Kawasaki Journal of Medical Welfare. Vol. 11 (1). 23-24. (2005). 